\title{
Distribution of Cows by Days in Milk (DIM) at First AI and Calving to Conception Interval in Dairy Cows
}

\author{
M. Yusuf*, A. L. Toleng, \& M. F. Syafar \\ Laboratory of Animal Reproduction, Department of Animal Production, \\ Faculty of Animal Science, Hasanuddin University, \\ Jln. Perintis Kemerdekaan Km 10 Makassar 90245, Indonesia \\ (Received 12-10-2012; Reviewed 14-12-2012; Accepted 26-12-2012)
}

\begin{abstract}
The objective of this study was to show the distribution of cows by days in milk (DIM) at first artificial insemination (AI) and the interval from calving to conception. The study was conducted in 47 commercial dairy herds in Enrekang Regency from May to October 2011. Of 289 animals, 143 of them or $49.5 \%$ were dairy Holstein Friesian cows with parities one to seven; mean $( \pm S D) 2.05 \pm 1.50$. The cows were classified into six groups based on DIM at first AI; within $40 \mathrm{~d}$ postpartum, between 41 and 85 d, 86 and 115 d, 116 and 150 d, 151 and 210 d, and 211 days or more. The cows were classified into five groups based on the interval from calving to conception; within $85 \mathrm{~d}$ postpartum, 86 and $115 \mathrm{~d}, 116$ and $150 \mathrm{~d}, 151$ and $210 \mathrm{~d}$, and 211 days or more. The results of this study showed that the interval from calving to first AI was 131.6 $\pm 121.8 \mathrm{~d}$. The percentage of cows inseminated within $85 \mathrm{~d}$ after calving was only $56.1 \%$; significantly lower $(\mathrm{P}<0.01)$ than the percentage in the list of fertility management assessment standard. Likewise, cows conceived within $150 \mathrm{~d}$ after calving was only $32 \%$. In conclusion, a longer average days in milk (DIM) at first AI in dairy cows was found in the present study, subsequently reduced the possibility of the cows to become pregnant in an optimum time, and reduced the reproductive performance of the herds.
\end{abstract}

Key words: days in milk at first AI, calving to conception interval, dairy cows

\section{ABSTRAK}

Tujuan penelitian ini adalah untuk menunjukkan distribusi ternak sapi perah pada inseminasi buatan (IB) pertama setelah melahirkan dan jarak antara melahirkan dan kembali bunting. Penelitian ini dilaksanakan pada 47 peternakan sapi perah dari bulan Mei sampai Oktober 2011 di Kabupaten Enrekang. Sebanyak 49,5\% dari 289 ternak merupakan induk dengan paritas satu sampai tujuh. Ternak sapi diklasifikasikan ke dalam enam kelompok berdasarkan pelaksanaan IB pertama, yaitu waktu 40 hari setelah melahirkan, antara 41 dan 85 hari, 86 dan 115 hari, 116 dan 150 hari, 151 dan 210 hari, dan 211 hari atau lebih. Ternak sapi diklasifikasikan ke dalam lima kelompok berdasarkan jarak antara melahirkan dan kembali bunting, yaitu waktu 85 hari setelah melahirkan, antara 86 dan 115 hari, 116 dan 150 hari, 151 dan 210 hari, dan 211 hari atau lebih. Hasil penelitian ini menunjukkan bahwa jarak antara melahirkan dan IB pertama adalah 131,6 $\pm 121,8$ hari. Persentase ternak yang diinseminasi dalam waktu 85 hari setelah melahirkan hanya sebesar $56,1 \%$, sangat nyata $(P<0,01)$ lebih rendah dibandingkan dengan standar persentase dalam daftar penilaian manajemen fertilitas. Ternak sapi perah yang bunting dalam waktu 150 hari setelah melahirkan hanya 32\%. Dapat disimpulkan bahwa rata-rata IB pertama setelah melahirkan dalam penelitian ini terlalu panjang, sehingga menurunkan kemungkinan ternak untuk kembali bunting dalam waktu yang optimal serta menurunkan penampilan reproduksi ternak sapi perah.

Kata kunci: IB pertama setelah melahirkan, jarak antara melahirkan dan kembali bunting, sapi perah

*Corresponding author:

E-mail: ramadhanti_yusuf@yahoo.com

Phone/fax.: +62-411-583111 


\section{INTRODUCTION}

Poor reproductive performance in dairy cows due to milk production is a worldwide problem and has been reported in many studies (Butler \& Smith, 1989; Beam \& Butler, 1999; Royal et al., 2000a; Nakada, 2006). Consequently, number of services per conception, delayed conception, and days open should have increased. Several factors have been recognized to reduce the reproductive performance in dairy cows. Study of Garcia-Ispierto et al. (2007) stated that risk factors for this problem included milking frequency, inseminator, inseminating bull, repeat breeding syndrome, lactation number and artificial insemination (AI) season. Likewise, occurrence of reproductive disorders as a limiting factor to improvement of reproductive performance was also suggested (Nakada, 2006). This sub-fertility has the highest economic cost and is the most difficult to treat (Royal et al., 2000b).

Reproductive performance is calculated using various indicators such as the number of days open (the interval between calving and successful of $\mathrm{AI}$ ) or the interval between successive calving. For an adequate evaluation of reproductive performance in a dairy herd, Esslemont \& Kossaibati (2000) has provided a list of fertility management assessment that we need to refer to certain standards. This list allows the producers to assess their herd performance grades from excellent to severe problem. For example, to be a good fertility management, 95\% cows in the herd after calving must be served by keeping the average calving to first service interval to less than $70 \mathrm{~d}$, more than $55 \%$ overall heat detection rate, and $50 \%$ or more of pregnancy rate. Therefore, to achieve an optimum standard of reproductive performance in a dairy herd, it is necessary to manage the herd and animals as appropriate manner.

Many studies have reported the reproductive performance in dairy cows at different locations (Macmillan et al., 1996; Washburn et al., 2002; Lopez-Gatius, 2003; Caraviello et al., 2006; Yusuf et al., 2010a). However, to our knowledge, it is still lacked information regarding the reproductive performance in dairy cows in South Sulawesi Province particularly the first inseminated time after calving and calving interval. Therefore, the objective of this study was to find out the distribution of cows by days in milk (DIM) at first AI and the interval from calving to conception.

\section{MATERIALS AND METHODS}

\section{Herds and animals}

The study was conducted in 47 small scale commercial dairy herds in Enrekang Regency, South Sulawesi Province during a period of six months; from May to October 2011. The herd size ranged from 1 to 15 animals (6.15 \pm 3.62 heads). In total 289 animals in all herds, 143 (49.5\%) heads were dairy Holstein Friesian (FH) cows that intensively concerning for this study with parities one to seven $(2.05 \pm 1.50)$. All the herds' management records were collected from the owners/farm staffs and/or by the authors. The voluntary waiting period (VWP) was
$40 \mathrm{~d}$ in all herds. Some cows which showed very clear signs of estrus were inseminated before VWP.

\section{Reproductive Management and Artificial Insemination}

In all herds, no estrous synchronization was used to induce estrus and detection of estrus was conducted by the farmers. Detection of estrus was based on secondary estrus signs due to that housing system in all herds were tie-stall. Cows detected in estrus were inseminated (AM/PM rule) by the designated inseminator using recto-vaginal technique with frozenthawed semen from proven $\mathrm{FH}$ or the others sires when $\mathrm{FH}$ semen was not available at the time of estrus. The cows that did not show symptoms of estrus during the $60 \mathrm{~d}$ or more after insemination were examined by rectal palpation to determine the pregnancy.

\section{Classification of Cows Based on DIM at First AI and Calving to Conception Interval}

Based on DIM at first AI (calving to first AI interval); the cows were classified into six groups which were: less than $40 \mathrm{~d}$ postpartum, between 41 and $85 \mathrm{~d}, 86$ and 115 d, 116 and $150 \mathrm{~d}, 151$ and $210 \mathrm{~d}$, and more than $211 \mathrm{~d}$ (Yusuf et al., 2011). Furthermore, based on the interval from calving to conception the cows were classified into five groups within $85 \mathrm{~d}$ postpartum, 86 and $115 \mathrm{~d}, 116$ and $150 \mathrm{~d}, 151$ and $210 \mathrm{~d}$, and more than $211 \mathrm{~d}$.

\section{Statistical Analyses}

All data were presented as mean \pm SD (standard deviation). Descriptive statistic was used to calculate the mean interval from calving to first AI and from calving to conception. The difference between percentage first inseminated cows within 85 days after calving and the standard DIM at first AI provided by Esslemont \& Kossaibati (2000) was analyzed using Chi-square test. Distribution of cows at different DIM at first AI, cumulative percentage of cows inseminated, and calving to conception interval were drawn.

\section{RESULTS AND DISCUSSION}

\section{Reproductive Performance of Dairy Cows}

DIM at First AI. The present study showed that calving to first AI intervals in dairy cows varies at different DIM. The mean interval from calving to first AI was 131.6 \pm 121.8 d, ranging from day 31 to 472 . Figure 1 shows the distribution of cows by DIM at first AI and cumulative percentage of cows inseminated. The percentage of cows inseminated within 40 and $85 \mathrm{~d}$ after calving was $12.2 \%$ and $56.1 \%$, respectively. The percentage of cows inseminated up to $210 \mathrm{~d}$ was $80.5 \%$ and the remaining $19.5 \%$ cows were first inseminated beyond $210 \mathrm{~d}$ after calving. These results were significantly lower (56.1 vs $90 \%$; Chi-square= 7.918; $\mathrm{df}=1 ; \mathrm{P}<0.01)$ than the list of fertility management assessment provided by Esslemont \& Kossaibati (2000) and subsequently reduced reproductive performance in the herds. 


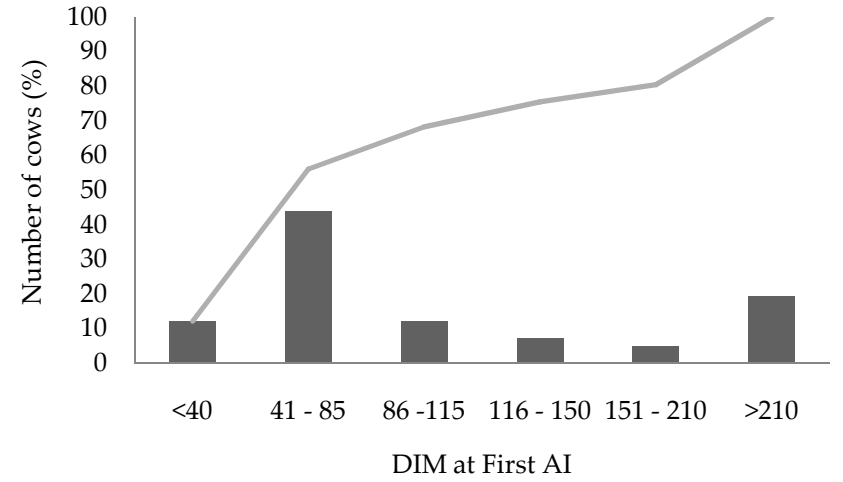

Figure 1. Distribution of cows at different days in milk (DIM) at first artificial insemination (AI) and cumulative percentage of cows inseminated

The causes of delayed first AI after calving in the present study were not fully understood and it is necessary to find out the factors contributed in. Previous studies reported that the causes of delayed first AI after calving in dairy cows include management and the cow factors (Yusuf et al., 2011), in which could be break down to the factors such as extended voluntary waiting period (Arbel et al., 2001), infection of the reproductive tract (Dohoo, 1983; Gilbert et al., 2005; Yusuf et al., 2011), season of calving, herd and parity (Darwash et al., 1997; Yusuf et al., 2011), abnormal resumption of ovarian cycle (Lamming \& Darwash, 1998; Yusuf et al., 2006; Yusuf et al., 2011), and negative energy balance (Lucy, 2001; Wiltbank et al., 2006). In this study, all cows were housed using tie-stall. This probably caused an extension of DIM at first AI. Cows in tie-stall herds have a significantly longer DIM at first AI in comparison with free-stall herds (Yusuf et al., 2011) and have a lower fertility index (Valde et al., 1997). Increased cow comfort in free-stall herds probably contributed to optimizing DIM at first AI (Bewley et al., 2001; Yusuf et al., 2011). Since there were so-many factors can contribute to the delayed first AI after calving, it was difficult to generalized as to predominant causes, therefore, each cow must be considered individually.

In the present study, all herds had no special recording for reproductive history of each cow. For this purpose, it is highly suggested to record all events in each cow during her productive time. This due to that in a small scale herds, a simple reproductive management such as recording is still difficult to conduct, resulting in difficulty to treat the individual cow. Furthermore, in order to improve the cows' reproductive performance it is necessary to examine the cows regularly and to record all events with the designated veterinarians.

Calving to Conception Interval and Number of AI. Figure 2 shows the interval from calving to conception in dairy cows. The results in this study showed that cows conceived within $150 \mathrm{~d}$ after calving was only 32\% (Figure 2), which was much lower than previously reported by Esslemont (1992), Darwash et al. (1997), Royal et al. (2000b), Yusuf et al. (2011). The average ( \pm SD) interval

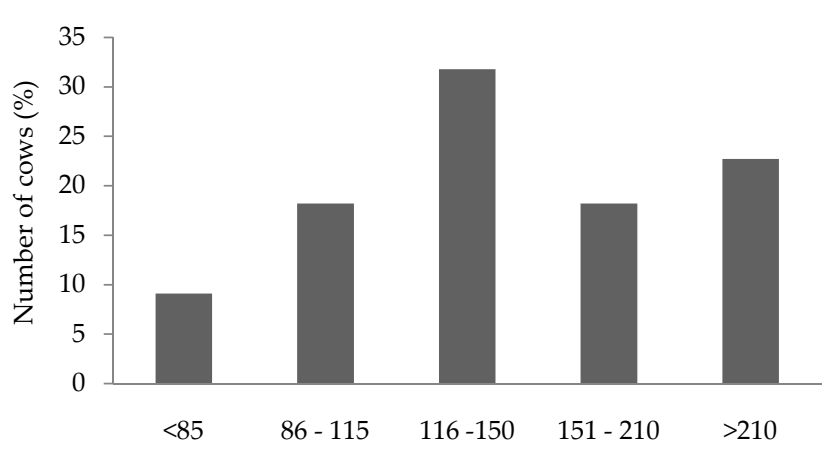

Days from calving to conception

Figure 2. Calving to conception interval of the cows at different days in milk (DIM)

from calving to conception in dairy cows in the present study was $179.2 \pm 93.9 \mathrm{~d}$, ranging from day 75 to 394 . These pregnant cows have been inseminated with average $( \pm \mathrm{SD})$ of $1.94 \pm 1.54$ times (Table 1$)$. Contrary for not pregnant cows, AI was conducted at average $( \pm \mathrm{SD})$ of $2.10 \pm 1.72$ times at the end of the study. This indicated that not all cows in the herds showed poor reproductive performance. On the other hand, a proportion of cows in the herds had better reproductive performance, and the other proportion had poor reproductive performance. If only a proportion of cows have had poor reproductive performance, attributed to declining fertility at the herd level, we need to pay specific attention to these cows to improve the herd fertility (Yusuf et al., 2010b). Their study also stated that approximately $60 \%$ cows in a herd have had poor fertility, leading to extend the interval from calving to conception. Uterine infection and ovarian disorders were two major factors contributed to reduced fertility (LeBlanc et al., 2002; Runciman et al., 2008; Yusuf et al., 2010a).

\section{Reproductive Failure in Dairy Cows}

Among the cows that failed to conceive, we investigated the average number of AI and intervals from calving to first AI for the cows inseminated three times or more (Table 2). At the end of the study period, we found that a total of 19 cows had been inseminated in average $( \pm \mathrm{SD})$ of $5.6 \pm 2.5$ times, and the average interval from calving to first AI was $199.0 \pm 49.5 \mathrm{~d}$. This indicated that

Table 1. Pregnancy status of the cows during the study period

\begin{tabular}{lcc}
\hline \multirow{2}{*}{ Parameter } & \multicolumn{2}{c}{ Pregnancy status } \\
\cline { 2 - 3 } & Pregnant & Not pregnant \\
\hline Number of cows (\%) & $70(49)$ & $73(51)$ \\
$\begin{array}{l}\text { Average number of artifi- } \\
\text { cial insemintaion }\end{array}$ & 1.94 & 2.1 \\
$\begin{array}{l}\text { Standard deviation } \\
\text { Confidence interval 95\% }\end{array}$ & 1.54 & 1.72 \\
\hline
\end{tabular}


Table 2. Number of artificial insemintaion (AI) and interval form calving to first $\mathrm{AI}$ in cows that failed to conceive after three times insemination $(n=19)$

\begin{tabular}{lcc}
\hline Parameter & Mean $( \pm$ SD) & Interval \\
\hline Age $(\mathrm{yr})$ & $4.8 \pm 1.7$ & $2-9$ \\
No. of AI & $5.6 \pm 2.5$ & $3-10$ \\
Interval from calving to & $199.0 \pm 49.5$ & $119-250$ \\
first AI & & \\
\hline
\end{tabular}

beside the cows was very late to inseminate, the cows also suffered from repeat breeding syndrome. This finding is in agreement with our previous study (Yusuf et al. 2010a) using 613 dairy Holstein Friesian cows that days in milk at first AI for the cows suffering from repeat breeding syndrome had longer than in normal fertility cows (194 vs $100 \mathrm{~d}$ ).

In the present study, no attempt was made to investigate the incidence of repeat breeding syndrome in dairy cows and the contributing factors. However, in our previous study (Yusuf et al., 2012), reported that the incidence of repeat breeding in this area was very high. Therefore, an intensive study is needed to depict the factors which contributing to the incidence of repeat breeding syndrome of dairy cows in this area. Several factors that might potentially described the incidence of repeat breeding in dairy cows have been studied by Bartlett et al. (1986), Bage et al. (2002), Moss et al., (2002). The previous study (Yusuf et al., 2010a) indicated that herd, parity, season of calving, resumption of postpartum ovarian cycles, and days in milk at first AI might be contribute in repeat breeding syndrome. The incidence of repeat breeding in this area probably caused by heat stress due to the hot humid weather in tropical condition, resulting in reduce fertility (Yusuf et al., 2012). When dairy cattle are subjected to heat stress, the reproductive efficiency will decline. Cows under heat stress will reduce duration and intensity of estrus, altered follicular development, and impaired of embryonic development (Jordan, 2003), resulting in an increased the chance to be repeat breeders (Macmillan et al., 1996; Roche et al., 2000).

\section{CONCLUSION}

A longer average days in milk (DIM) at first AI in dairy cows was found in the present study, subsequently reduced the possibility of the cows to become pregnant in an optimum time, and reduced the reproductive performance of the herds.

\section{ACKNOWLEDGMENT}

The authors are thankful to the dairy farmers in Enrekang Regency for their cooperation and kind help during the study period. Our sincere thanks are due to Mr. A. Edwi Oktadiawan Noor and Muhammad Aksan for their help in collecting data.

\section{REFERENCES}

Arbel, R., Y. Bigun, E. Ezra, H. Sturman, \& D. Hojman. 2001. The effect of extended calving intervals in high lactating cows on milk production and profitability. J. Dairy Sci. 84: 600608. http://dx.doi.org/10.3168/jds.S0022-0302(01)74513-4

Bage, R., H. Gustafsson, B. Larsson, M. Forsberg, \& H. Rodríguez-Martínez. 2002. Repeat breeding in dairy heifers: follicular dynamics and estrous cycle characteristics in relation to sexual hormone patterns. Theriogenology 57: 2257-2269. http://dx.doi.org/10.1016/S0093-691X(02)008403

Bartlett, P. C., J. H. Kirk, \& E. C. Mather. 1986. Repeated insemination in Michigan Holstein Friesian cattle: incidence, descriptive epidemiology and estimated economic impact. Theriogenology 26: 309-322. http://dx.doi. org/10.1016/0093-691X(86)90150-0

Beam, S. W., \& W. R. Butler. 1999. Effects of energy balance on follicular development and first ovulation in post partum dairy cows. J. Reprod. Fertil. 54 (Suppl) 411-424.

Bewley, J., R. W. Palmer, \& D. B. Jackson-Smith. 2001. A comparison of free-stall barns used by modernized Wisconsin dairies. J. Dairy Sci. 84: 528-541. http://dx.doi.org/10.3168/ jds.S0022-0302(01)74504-3

Butler, W. R. \& R. D. Smith. 1989. Interrelationships between energy balance and postpartum reproductive function in dairy cattle. J. Dairy Sci. 72: 767-783. http://dx.doi. org/10.3168/jds.S0022-0302(89)79169-4

Caraviello, D. Z., K. A. Weigel, M. Craven, D. Gianola, N. B. Cook, K. V. Nordlund, P. M. Fricke, \& M. C. Wiltbank. 2006. Analysis of reproductive performance of lactating cows on large dairy farms using machine learning algorithms. J. Dairy Sci. 89:4703-4722. http://dx.doi.org/10.3168/ jds.S0022-0302(06)72521-8

Darwash, A. O., G. E. Lamming, \& J. A. Woolliams. 1997. The phenotypic association between the interval to postpartum ovulation and traditional measures of fertility in dairy cattle. Anim. Sci. 65: 9-16. http://dx.doi.org/10.1017/ S1357729800016234

Dohoo, I. R. 1983. The effects of calving to first service interval on reproductive performance in normal cows and cows with postpartal disease. Can. Vet. J. 24: 343-346.

Esslemont, R. J. 1992. Measuring dairy herd fertility. Vet. Rec. 131: 209-212. http://dx.doi.org/10.1136/vr.131.10.209

Esslemont, R. J. \& M. A. Kossaibati. 2000. The use of databases to manage fertility. Anim. Reprod. Sci. 60-61: 725-741. http://dx.doi.org/10.1016/S0378-4320(00)00081-6

Garcia-Ispierto, I., F. Lopez-Gatius, P. Santolaria, J. L. Yaniz, C. Nogareda, \& M. Lopez-Bejar. 2007. Factors affecting the fertility of high producing dairy herds in northeastern Spain. Theriogenology 67: 632-638. http://dx.doi. org/10.1016/j.theriogenology.2006.09.038

Gilbert, R. O., S. T. Shin, C. L. Guard, H. N. Erb, \& M. Frajblat. 2005. Prevalence of endometritis and its effects on reproductive performance of dairy cows. Theriogenology 64: 1879-1888. http://dx.doi.org/10.1016/j.theriogenology.2 005.04.022

Jordan, E. R. 2003. Effects of heat stress on reproduction. J. Dairy Sci. 86: (E. Suppl.) E104-E114.

Lamming, G. E. \& A. O. Darwash. 1998. The use of milk progesterone profiles to characterise components of subfertility in milked dairy cows. Anim. Reprod. Sci. 52: 175-190. http://dx.doi.org/10.1016/S0378-4320(98)00099-2

LeBlanc, S. J., T. F. Duffield, K. E. Leslie, K. G. Bateman, G. P. Keefe, J. S. Walton, \& W. H. Johnson. 2002. Defining and diagnosing postpartum clinical endometritis and its impact on reproductive performance in dairy cows. J. Dairy Sci. 85: 2223-2236. http://dx.doi.org/10.3168/jds.S00220302(02)74302-6 
Lopez-Gatius, F. 2003. Is fertility declining in dairy cattle? A retrospective study in northeastern Spain. Theriogenology 60: 89-99.

Lucy, M. C. 2001. Reproductive loss in high-producing dairy cattle: where will it end? J. Dairy Sci. 84: 1277-1293. http:// dx.doi.org/10.3168/jds.S0022-0302(01)70158-0

Macmillan, K. L., I. J. Lean, \& C. T. Westwood. 1996. The effects of lactation on the fertility of dairy cows. Aust. Vet. J. 73: 141-147. http://dx.doi.org/10.1111/j.1751-0813.1996. tb10007.x

Moss, N., I. J. Lean, S. W. J. Reid, \& D. R. Hodgson. 2002. Risk factors for repeat-breeder syndrome in New South Wales dairy cows. Prev. Vet. Med. 54: 91-103. http://dx.doi. org/10.1016/S0167-5877(02)00016-8

Nakada, K. 2006. How to improve reproductive efficacy from now in Japan? Find out the factors of late lactation to predict postpartum reproductive diseases. J. Reprod. Dev. 52: 177-183. http://dx.doi.org/10.1262/jrd.17090

Roche, J. F., D. Mackey, \& M. D. Diskin. 2000. Reproductive management of postpartum cows. Anim. Reprod. Sci. 6061: 703-712. http://dx.doi.org/10.1016/S0378-4320(00)00107$\mathrm{X}$

Royal, M. D., A. O. Darwash, A. P. F. Flint, R. Webb, J. A. Woolliams, \& G. E. Lamming. 2000a. Declining fertility in dairy cattle: changes in traditional and endocrine parameters of fertility. Anim. Sci. 70: 487-501.

Royal, M. D., J. E. Pryce, J. A. Woolliams, \& A. P. F. Flint. 2002b. The genetic relationship between commencement of luteal activity and calving interval, body condition score, production and linear type traits in Holstein-Friesian dairy cattle. J. Dairy Sci. 85: 3071-3080. http://dx.doi.org/10.3168/ jds.S0022-0302(02)74394-4

Runciman, D. J., G. A. Anderson, J. Malmo, \& G. M. Davis. 2008. Use of postpartum vaginoscopic (visual vaginal) examination of dairy cows for the diagnosis of endometritis and the association of endometritis with reduced reproductive performance. Aust. Vet. J. 86: 205-213. http://dx.doi. org/10.1111/j.1751-0813.2008.00301.x
Valde, J. P., D. W. Hird, M. C. Thurmond, \& O. Osterås. 1997. Comparison of ketosis, clinical mastitis, somatic cell count, and reproductive performance between free stall and tie stall barns in Norwegian dairy herds with automatic feeding. Acta Veterinaria Scandinavica 38: 181-192.

Washburn, S. P., W. J. Silvia, C. H. Brown, B. T. McDaniel, \& A. J. McAllister. 2002. Trends in reproductive performance in southeastern Holstein and Jersey DHI herds. J. Dairy Sci. 85: 244-251. http://dx.doi.org/10.3168/jds.S00220302(02)74073-3

Wiltbank, M., H. Lopez, R. Sartori, S. Sangsritavong, \& A. Gumen. 2006. Changes in reproductive physiology of lactating dairy cows due to elevated steroid metabolism. Theriogenology 65: 17-19. http://dx.doi.org/10.1016/j.theriogenology.2005.10.003

Yusuf, M., L. Rahim, M. A. Asja, \& A. Wahyudi. 2012. The incidence of repeat breeding in dairy cows under tropical condition. Med. Pet. 35:28-31. http://dx.doi.org/10.5398/ medpet.2012.35.1.28

Yusuf, M., T. Nakao, C. Yoshida, S. T. Long, G. Gautam, R. M. S. B. K. Ranasinghe, K. Koike, \& A. Hayashi. 2011. Days in milk at first AI in dairy cows; Its effect on subsequent reproductive performance and some factors influencing it. J. Reprod. Dev. 57:653-659. http://dx.doi.org/10.1262/jrd.10097T

Yusuf, M., T. Nakao, \& M. Ogawa. 2006. Effects of interval between calving and first ovulation on ovarian cycles postpartum and conception rate in high-producing dairy cows. J. Reprod. Dev. 52 (suppl) j67.

Yusuf, M., T. Nakao, R. M. S. B. K. Ranasinghe, G. Gautam, S. T. Long, C. Yoshida, K. Koike, \& A. Hayashi. 2010a. Reproductive performance of repeat breeders in dairy herds. Theriogenology 73: 1220-1229. http://dx.doi.org/10.1016/ j.theriogenology.2010.01.016

Yusuf, M., T. Nakao, S. T. Long, \& G. Gautam. 2010b. Analysis of some factors affecting fertility levels in a high-producing dairy herd in south-western Japan. Anim. Sci. J. 81: 467474. http://dx.doi.org/10.1111/j.1740-0929.2010.00764.x 